\title{
Antimicrobial activity of lozenge with garlic bulb powder
}

\author{
Tatjana D. Kundaković ${ }^{1}$, Ana D. Ćirić ${ }^{2}$, Marina D. Soković ${ }^{2}$, Marina T. Milenković ${ }^{3}$, Vesna D. Nikolić ${ }^{4}$, \\ Goran S. Nikolic ${ }^{4}$ \\ ${ }^{1}$ Department of Pharmacognosy, University of Belgrade, Faculty of Pharmacy, Belgrade, Serbia \\ ${ }^{2}$ Institute for Biological Research "Siniša Stanković", University of Belgrade, Belgrade, Serbia \\ ${ }^{3}$ Department of Microbiology and Immunology, University of Belgrade, Faculty of Pharmacy, Belgrade, Serbia \\ ${ }^{4}$ Department of Organic Chemical Technology, University of Niš, Faculty of Technology, Leskovac, Serbia
}

\begin{abstract}
According to the tested antimicrobial activity of constituents and their chemical characteristics, a new formulation of oral antiseptic was made based on garlic bulb powder and its active principles with strong antimicrobial activity against a wide range of bacteria and fungi. The antimicrobial activity of garlic bulb powder, allicin and the lozenge with $15 \%$ of garlic powder was tested using broth microdilution method. The tested garlic powder, as well the lozenge, have shown very high antimicrobial activity with MIC $1.25-5.00 \mathrm{mg} / \mathrm{ml}$, and $1.87-7.50 \mathrm{mg} / \mathrm{ml}$, respectively. The major compound, allicin, was highly active at a very low concentration. The minimal inhibitory concentration of allicin was from 6.25-12.50 $\mu \mathrm{g} / \mathrm{ml}$ for antibacterial activity and $0.4 \mu \mathrm{g} / \mathrm{ml}$ for antifungal activity. Those concentrations are comparable with concentrations of commercially available antibiotics and fungicides. The formulation of an antiseptic with herbal constituents, high antibacterial and antifungal activity and pleasant taste could be an alternative to classical pharmaceutical oral antiseptics.
\end{abstract}

Keywords: Allium sativum; allicin; lozenge; antimicrobial activity.

\section{SCIENTIFIC PAPER}

UDC 615.282:615.451.1:635.26

Hem. Ind. 65 (5) 607-610 (2011)

doi: 10.2298/HEMIND110414048K

Available online at the Journal website: http://www.ache.org.rs/HI/

The antimicrobial properties of garlic (Allium sativum, Liliaceae) have been shown in many studies against a broad range of Gram-positive and Gram-negative bacteria and fungi including highly multidrug-resistant pathogens. Alliin is the stable precursor and transformed to allicin in the presence of enzyme alliinase after the crushing the garlic clove. Allicin is very unstable and decomposes rapidly. In the degradation process of garlic bulb preparation, different compounds can be obtained depending on the environment in which the preparation exists. The antibacterial and antifungal activity was attributed to the major compound, allicin [1,2]. The exact mechanism of antibacterial activity of allicin is probably due to the inhibition of sulfhydryl enzymes. Addition of thiols inhibits the antimicrobial activity of allicin [3]. Antifungal effects of allicin or garlic extracts were more pronounced against Candida albicans and Trychophyton sp. [4-6], but significant activity was obtained against some other fungi, like Aspergillus, Penicillium, Fusarium and Trichoderma species $[7,8]$. The most important is the high activity against some resistant bacteria (vancomycin-resistant enterococci, Staphylococcus sp., Mycobacterium sp. and Helicobacter

Correspondence: T.D. Kundaković Department of Pharmacognosy, Faculty of Pharmacy, Vojvode Stepe 450, 11221 Belgrade, Serbia.

E-mail: ktatjana@pharmacy.bg.ac.rs

Paper received: 14 April, 2011

Paper accepted: 24 May, 2011 pylori) $[3,9,10]$. Also, the compounds from garlic possess antiviral and antiprotozoal activities [3,11].

Garlic is a food, as well as a medicine. The different extracts of Allium sativum can prevent platelet aggregation, possess hypotensive effect [12], induce natriuretic and diuretic effect with prolonged hypotensive activity [13], influence the level of cholesterol and triglycerides and be useful in prevention of dyslipidemia [14]. Also, the constituents of garlic bulb can modulate immune system and possess antioxidant and anticancer properties showed in vitro [15--17].

Our research was based firstly to develop a new method for the production of stabile Allium sativum bulb powder, to evaluate its antimicrobial activity and then to prepare a lozenge with antiseptic properties. According to our previous results, the most stable garlic product was obtained after water extraction of garlic bulb powder. The percentage of allicin was the same as in fresh garlic bulb, and stable for 18 months when stored at $0{ }^{\circ} \mathrm{C}$ [18]. Our recent paper showed that pure allicin and allicin incorporated in gel exhibited significant antimicrobial activity against five microorganisms using the disc diffusion method [19]. In this study, the antimicrobial activity of garlic bulb powder, its major compound allicin obtained by synthesis and a lozenge prepared with garlic bulb powder was tested against a broad range of bacteria and fungi using broth microdillution method. 


\section{EXPERIMENTAL}

Garlic bulb powder (Allii sativi bulbi pulvis, Allium sativum L., Liliaceae) was prepared according to the method given by Nikolić et al. [18]. Briefly, the freshly powdered garlic bulb was extracted using water, and after filtration, the residue was dried and used for preparation of the lozenge. The lozenge with garlic bulb powder (15\%), sorbitol, PVP K-30 and Mg stearate were made using wet granulation method in fluidized layer. Allicin, the major active compound in garlic, was obtained by synthesis [20]. The content of allicin was determined at the beginning of the study in garlic bulb powder, as well in the lozenge. The analytical method from Ph. Eur. 6.0 was suitable for determination of allicin in garlic bulb powder extract, as well in lozenge [21]. Menthol was obtained from Sigma-Aldrich.

\section{Antimicrobial activity}

The antimicrobial activity of garlic bulb powder, its major compound allicin and a lozenge prepared with garlic bulb powder was tested against Gram-positive and Gram-negative bacteria and fungi using the broth microdilution method.

The antimicrobial activity of garlic powder, allicin and lozenge was evaluated in vitro using six different laboratory control strains of bacteria - Gram-positive: Staphylococcus aureus (ATCC 25923), Micrococcus flavus (ATCC 10240), Enterococcus faecalis (ATCC 29212), Bacillus subtilis (ATCC 6633) and Gram-negative: Escherichia coli (ATCC 25922), Pseudomonas aeruginosa (ATCC 27853), and yeast Candida albicans (ATCC 10231). Microorganisms were provided by the Institute for Immunology and Virology, Torlak, Belgrade. A broth microdilution method was used to determine minimal inhibitory concentration (MIC) of extracts according to Clinical and Laboratory Standards Institute [22].

All tests were performed in Müller Hinton broth for bacterial strains and in Sabouraud dextrose broth for Candida albicans. Overnight broth cultures of each strain were prepared and the final concentration in each well was adjusted to $2 \times 10^{6} \mathrm{CFU} / \mathrm{ml}$ for bacteria and $2 \times 10^{5} \mathrm{CFU} / \mathrm{ml}$ for yeasts. Minimum inhibitory concentrations (MICs) determination was performed by a serial dilution technique using 96-well microtitre plates. The investigated compounds (allicin and menthol) were dissolved in DMSO/ $\mathrm{H}_{2} \mathrm{O}=50: 50(1 \mathrm{mg} / \mathrm{ml})$, the garlic powder dissolved in $\mathrm{DMSO} / \mathrm{H}_{2} \mathrm{O}=50: 50(10 \mathrm{mg} / \mathrm{ml})$ and a lozenge in water $(15 \mathrm{mg} / \mathrm{ml})$, and added in broth medium with inoculum. In the tests, triphenyl tetrazolium chloride (TTC) (Aldrich Chemical Company Inc., USA) was also added to the culture medium as a growth indicator. The final concentration of TTC after inoculation was $0.05 \%$. The microbial growth was determined by absorbance at $600 \mathrm{~nm}$ using universal microplate reader after incubation at $37{ }^{\circ} \mathrm{C}$ for $24 \mathrm{~h}$ for bacteria, and at $25{ }^{\circ} \mathrm{C}$ for $48 \mathrm{~h}$ for fungi. The MIC is defined as the lowest concentration of the compound at which the microorganism does not demonstrate visible growth.

$\mathrm{DMSO} / \mathrm{H}_{2} \mathrm{O}$ and water were used as a negative control and amikacin, ampicillin and nystatin were used as positive controls $(0.1-5 \mu \mathrm{l} / \mathrm{ml})$. All determinations were performed in duplicate and two positive growth controls were included.

\section{RESULTS AND DISCUSSION}

The antimicrobial activity of garlic bulb powder, allicin and the lozenge with $15 \%$ of garlic powder was tested using the broth microdilution method. The average percentage of allicin in the garlic bulb powder at the beginning of experiment was $2.7 \pm 0.02 \%$, determinated by HPLC method in Ph. Eur. 6.0 monograph for Allii sativi bulbi pulvis. The average quantity of allicin in one lozenge was $0.0010 \pm 0.0005 \mathrm{~g}$.

The results are given in Table 1 . The tested garlic bulb powder, as well the lozenge, have shown very high antimicrobial activity with MIC $1.25-5.00 \mathrm{mg} / \mathrm{ml}$, and $1.87-7.50 \mathrm{mg} / \mathrm{ml}$, respectively. Garlic powder was especially active against C. albicans (MIC $1.25 \mathrm{mg} / \mathrm{ml}$ ), while lozenge has shown high activity against $E$. faecalis and B. subtilis with MIC $1.87 \mathrm{mg} / \mathrm{ml}$, as well against $C$. albicans (MIC $7.50 \mathrm{mg} / \mathrm{ml}$ ). The major compound allicin was highly active in very low concentration. Minimum inhibitory concentration of allicin was from 6.25-12.50 $\mu \mathrm{g} / \mathrm{ml}$ for antibacterial activity and $0.40 \mu \mathrm{g} / \mathrm{ml}$ for antifungal activity. Those concentrations are comparable with concentrations of commercially available antibiotics and fungicides. Menthol, used to adjust taste and smell, partly influenced the antimicrobial activity, because much higher concentrations were needed to inhibit the growth of tested microorganisms (MIC 9.70$-312.50 \mu \mathrm{g} / \mathrm{ml}$ ) compared to allicin, except in cases of $E$. faecalis and $B$. subtilis where garlic extract exhibited lower activity then lozenge.

Our results are in accordance with previous studies of antimicrobial activity of allicin, as well of garlic extract, and confirm the major role of allicin in antimicrobial activity. A very important finding was the high activity of the lozenge against $C$. albicans, a very common cause of oral cavity infection. The formulated antiseptic product was characterized by the state of solid solution where the active compounds were molecularly dispersed in polymer matrix (sorbitol) with good solubility in water and with large specific area. The good solubility and large specific area are important for good releasing of active principles from garlic powder (allicin). Besides the high antimicrobial activity, lozenge possess pleasant taste and refreshing breath properties, so could be used as natural antiseptic in prevention and treatment of infections of oral and throat mucosa. 
Table 1. Minimum inhibitory concentrations (MICs) of allicin, menthol, garlic powder and lozenge against selected bacteria and fungi

\begin{tabular}{|c|c|c|c|c|c|c|c|}
\hline \multirow{2}{*}{ Microorganism } & Lozenge & Garlic powder & Allicin & Menthol & Amikacin & Ampicillin & Nystatin \\
\hline & \multicolumn{2}{|c|}{$\mathrm{mg} / \mathrm{ml}$} & \multicolumn{5}{|c|}{$\mu \mathrm{g} / \mathrm{ml}$} \\
\hline Staphylococcus aureus & 7.50 & 2.50 & 6.25 & 19.00 & 2.0 & 1.0 & n.t. ${ }^{a}$ \\
\hline Micrococcus flavus & 3.75 & 2.50 & 6.25 & 19.00 & n.t. & n.t. & n.t. \\
\hline Enterococcus faecalis & 1.87 & 5.00 & 12.50 & 9.70 & 2.4 & n.t. & n.t. \\
\hline Bacillus subtilis & 1.87 & 5.00 & 6.25 & 2.50 & $-{ }^{b}$ & - & - \\
\hline Escherichia coli & 3.75 & 2.50 & 12.50 & 312.50 & 8.6 & 4.4 & n.t. \\
\hline Pseudomonas aeruginosa & 15.00 & 5.00 & 6.25 & 312.50 & 2.8 & n.t. & n.t. \\
\hline Candida albicans & 7.50 & 1.25 & 0.40 & 15.60 & n.t. & n.t. & 3.8 \\
\hline
\end{tabular}

${ }^{a}$ Not tested; ${ }^{b}$ not active

\section{CONCLUSION}

A new formulation of oral antiseptic was made based on garlic bulb powder and its active principles with strong antimicrobial activity against wide range of Gram-positive and Gram-negative bacteria and yeast C. albicans. The antimicrobial activity of garlic bulb powder, allicin and the lozenge with $15 \%$ of garlic powder was tested using the broth microdilution method. The tested garlic powder, as well the lozenge, have shown very high antimicrobial activity, due to the presence of major compound allicin with high activity at a very low concentration. The minimal inhibitory concentration of allicin was from $6.25-12.50 \mu \mathrm{g} / \mathrm{ml}$ against bacteria and $0.40 \mu \mathrm{g} / \mathrm{ml}$ against $C$. albicans. Menthol, which was used to correct smell and taste, also possessed high antimicrobial activity, but lower than allicin. The higher antimicrobial activity then garlic powder was obtained against $E$. faecalis and $B$. subtilis, so the activity of the lozenge against those two bacteria was probably due to the presence of menthol.

Because of high antimicrobial activity and good solubility, new formulation of lozenge could be used as natural antiseptic in prevention and treating of infections of oral and throat mucosa. Also, lozenges with menthol possess pleasant taste and refreshing breath properties which is important because of presence of sulphur-containing compounds from garlic. The formulation of an antiseptic with herbal constituents and high antibacterial and antifungal activity could be an alternative to commercial oral antiseptics.

\section{Acknowledgements}

Authors wish to express their gratitude to the Ministry of Education and Science of the Republic of Serbia (Projects No. 173021, 34012 and 173032) for financial support of this study.

\section{REFERENCES}

[1] G. Aviello, L. Abenavoli, F. Borrelli, R. Capasso, A.A. Izzo, F. Lembo, B. Romano, F.C apasso, Garlic: Empiricism or science?, Nat. Prod. Com. 4 (2009) 1785-1796
[2] H. Fujisawa, K. Watanabe, K. Suma, K. Origuchi, H. Matsufuji, T. Seki, T. Ariga, Antibacterial potential of garlicderived allicin and its cancellation by sulfhydryl compounds, Biosci. Biotechnol. Biochem. 73 (2009) 1948$-1955$

[3] S. Ankri, D. Mirelman, Antimicrobial properties of allicin from garlic, Mic. Inf. 2 (1999) 125129

[4] A. Khodavandi, F. Alizadeh, N.S. Harmal, S.M. Sidik, F. Othman, Z. Sekawi, M.A.F. Jahromi, K.P. Ng, P.P. Chong, FEMS Microbiol. Let. 315 (2011) 87-93

[5] F. Aala, U.K. Yusuf, A. Khodavandi, F. Jamal, In vitro antifungal activity of allicin alone and in combination with two medications against six dermatophytic fungi, AMRJ 4 (2010) 380-385

[6] M.S. Pyun, S. Shin, Antifungal effects of the volatile oils from Allium plants against Trichophyton species and synergism of the oils with ketoconazole, Phytomedicine $\mathbf{1 3}$ (2006) 394-400

[7] P. Tedeschi, A. Maietti, M. Boggian, G. Vecchiati, V. Brandolini, Fungitoxicity of lyophilized and spray-dried garlic extracts, J. Enviroment. Sci. Health-Part B 42 (2007) 795-799

[8] P.F. Cavagnaro, A. Camargo, R.J. Piccolo, S.G. Lampasona, J.L. Burba, R.W. Masuelli, Resistance to Penicillium hirsutum Dierckx in garlic accessions, Eur. J. Plant Pathol. 112 (2005) 195-199

[9] R. Gautam, A. Saklani, S.M. Jachak, Indian medicinal plants as a source of antimycobacterial agents, J. Ethnopharmacol. 110 (2007) 200-234

[10] G.P. Sivam, J.W. Lampe, B. Ulness, S.R. Swanzy, J.D. Potter, Helicobacter pylori-in vitro susceptibility to garlic (Allium sativum) extract, Nutr. Cancer. 27 (1997) 118$-121$

[11] J.C. Harris, S.L. Cottrell, S. Plummer, D. LLoyd, Antimicrobial properties of Allium sativum (garlic), Appl. Microbiol. Biotechnol. 57 (2001) 282-286

[12] F.S. Bethaei, S. Akhondzadeh, Cardiovascular effects of Allium sativum (garlic): An evidence-based review, J. Tehran Univ. Heart Cent. 3 (2008) 5-10

[13] C.V. Pantoja, N.T. Martin, B.C. Norris, C.M. Contreras, Purification and bioassays of a diuretic and natriuretic fraction from garlic (Allium sativum), J. Ethnopharmacol. 70 (2000) 35-40 
[14] C.R. Sirtori, C. Galli, J.W. Anderson, E. Sirtori, A. Arnoldi, Functional foods for dyslipidaemia and cardiovascular risk prevention, Nutr. Res. Rev. 22 (2009) 244-261

[15] F. Clement, Y.P. Venkatesh, Dietary garlic (Allium sativum) lectins, ASA I and ASA II, are highly stable and immunogenic, Int. Immunopharmacol. 10 (2010) 1161$-1169$

[16] M. Koseoglu, F. Isleten, A. Atay, Y.C. Kaplan, Effects of acute and subacute garlic supplement administration on serum total antioxidant capacity and lipid parameters in healthy volunteers, Phytother. Res. 24 (2010) 374-378

[17] M. Iciek, I. Kwiecieri, L. Wlodek, Biological properties of garlic and garlic-derived organosulfur compounds, Env. Mol. Mut. 50 (2009) 247-265

[18] V.D. Nikolić, M. Stanković, Nikolić Lj.B., D.U. Skala, HPLC analysis of thiosulphinates in aqueous extracts from garlic (Allium sativum L.), Hem. Ind. 55 (2001) 120-124
[19] D.P. Ilić, V.D. Nikolić, Lj.B., Nikolić, M.Z. Stanković, Lj.P. Stanojević, Thermal degradation, antioxidant and antimicrobial activity of synthesized allicin and allicin incurporated in gel, Hem. Ind. 64 (2010) 85-91

[20] V.D. Nikolić, M. Stanković, Lj.B. Nikolić, D. Cvetkovic, Allylthosulfinate: beta-cyclodextrin inclusion complex: preparation, characterization and microbiological activity, Pharmazie 59 (2004) 10-14

[21] Ph. Eur. 6.0., European Pharmacopoeia, $6^{\text {th }}$ ed., Council of Europe, Strasbourg, France, 2010.

[22] Clinical and Laboratory Standards Institute (CLSI): Performance standards for antimicrobial susceptibility testing: $15^{\text {th }}$ informational supplement. CLSI document M100-S15, Wayne, PA, USA; 2005.

\title{
IZVOD
}

\section{ANTIMIKROBNA AKTIVNOST LOZENGI SA PRAŠKOM BELOG LUKA}

\author{
Tatjana D. Kundaković ${ }^{1}$, Ana D. Ćirić ${ }^{2}$, Marina D. Soković ${ }^{2}$, Marina T. Milenković ${ }^{3}, V_{\text {Vesna D. Nikolić }}^{4}$, Goran S. Nikolić $^{4}$ \\ ${ }^{1}$ Katedra za farmakognoziju, Farmaceutski fakultet, Univerzitet u Beogradu, Beograd, Srbija \\ ${ }^{2}$ Institut za biološka istraživanja „Siniša Stanković", Univerzitet u Beogradu, Beograd, Srbija \\ ${ }^{3}$ Katedra za mikrobiologiju i imunologiju, Farmaceutski fakultet, Univerzitet u Beogradu, Beograd, Srbija \\ ${ }^{4}$ Katedra za organsku hemijsku tehnologiju, Tehnološki fakultet, Univerzitet u Nišu, Leskovac, Srbija
}

\section{(Naučni rad)}

Na osnovu ispitane antimikrobne aktivnosti komponenata i njihovih hemijskih karakteristika, napravljena je nova formulacija oralnog antiseptika koji kao aktivnu komponentu ima prašak belog luka čiji sastojci pokazuju veoma izraženu aktivnost protiv širokog spektra bakterija i gljive Candida albicans. Antimikrobna aktivnost praška belog luka, alicina i lozengi sa $15 \%$ praška belog luka je ispitivana bujon mikrodilucionom metodom. Testiran prašak belog luka, kao i lozenge imaju veoma jaku antimikrobnu aktivnost sa minimalnim inhibitornim koncentracijama (MIC) $1,25-5,00 \mathrm{mg} / \mathrm{ml}$ (prašak belog luka) i 1,87-7,50 mg/ml (lozenge). Glavna aktivna komponeta belog luka, alicin, pokazuje antimikrobnu aktivnost u veoma niskim koncentracijama. Minimalne inhibitorne koncentracije alicina se kreću od 6,25$-12,5 \mu \mathrm{g} / \mathrm{ml}$ protiv bakterija i $0,4 \mu \mathrm{g} / \mathrm{ml}$ protiv gljivice Candida albicans. Ove koncentracije se mogu uporediti sa koncentracijama komercijalnih antibiotika i fungicida. Naši rezultati su u skladu sa prethodnim ispitivanjima alicina i različitih ekstrakta belog luka, i potvrđuju najvažniju ulogu alicina u antimikrobnoj aktivnosti. Veoma je važna visoka aktivnost ovako formulisanog oralnog preparata protiv gljivice $C$. albicans koja je čest uzročnik infekcija usne duplje. Formulisan proizvod sa antiseptičkim osobinama karakteriše stanje čvrstog rastvora gde su aktivne supstance molekularno-disperzno ugrađene u obliku dobro rastvornog polimernog matriksa (sorbitola) velike specifične površine. Dobra rastvorljivost polimernog matriksa i velika specifična površina omogućuju zadovoljavajuću brzinu otpuštanja aktivnih principa iz belog luka (alicin). Pored visoke antimikrobne aktivnosti, lozenge poseduju prijatan ukus i osvežavaju dah, pa se mogu koristiti kao prirodni antiseptik u prevenciji i terapiji infekcija sluzokože usta i ždrela. Formulacija antiseptika sa biljnim sastojcima i visokom antibakterijskom i antifungalnom aktivnošću može biti alternativa farmaceutskim oralnim antisepticima.
Ključne reči: Allium sativum • Alicin • Lozenge $\bullet$ Antimikrobna aktivnost 